BORE JEGDIĆ, JOVAN POPIĆ, BILJANA BOBIĆ, MAJA STEVANOVIĆ

${ }^{1}$ University of Belgrade, Institute of chemistry, technology and metallurgy, Department of electrochemistry, Belgrade, Serbia
Review paper

ISSN 0351-9465, E-ISSN 2466-2585

UDC: $620.193 .4: 669-4$

doi:10.5937/ZasMat1602205J

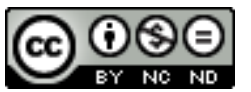

Zastita Materijala 57 (2)

$205-211$ (2016)

\title{
Chemical corrosion of metals and alloys
}

\begin{abstract}
In this paper, phenomena of chemical corrosion of metals and alloys in electrolyte solutions are analyzed. It is shown that iron, chromium and other metals and alloys dissolve much faster than is the corrosion rate determined by electrochemical methods. This means that the chemical dissolution takes place simultaneously with the electrochemical dissolution. The chemical dissolution does not depend on electrode potential. Under some conditions, chemical dissolution of metals is the dominant process of dissolution. Several mechanisms of chemical corrosion are described. Also, the consequences of chemical dissolution of various metals and alloys are discussed, as well as the hydrogen evolution during the chemical dissolution. The process of hydrogen evolution during the chemical corrosion is not subjected to the laws of electrochemical kinetics.
\end{abstract}

Keywords: corrosion, chemical dissolution, electrochemical dissolution, iron, chromium.

\section{INTRODUCTION}

It was observed that iron, chromium and other metals in electrolyte solutions dissolve faster than their dissolution rates determined by electrochemical methods. This indicates that simultaneously with the electrochemical dissolution the chemical dissolution takes place. Several electrochemical methods were developed to determine the corrosion rate of metals. The extrapolation of Tafel lines to the corrosion potential gives the current density of anodic dissolution of metal, which is at the same time the corrosion current density, $j_{\text {corr. }}$ Besides the Tafel extrapolation method, polarization measurements at low polarizations (Stern-Geary's method [1]) and electrochemical impedance spectroscopy method [2] have been widely used in practice. Many commercially available devices for measuring corrosion rate of metals and alloys were made, based on these methods.

Pražak [3] has noted that in many cases values of corrosion rate obtained by gravimetric or analytical methods are higher than those obtained by the polarization resistance method. For these reasons,

${ }^{*}$ Corresponding author: Bore Jegdić

E-mail: borejegdic@yahoo.com

Paper received 25. 12. 2015.

Paper accepted 21. 01.2016.

Paper is available on the website:

www.idk.org.rs/journal
Pražak has proposed the use of correction factors for electrochemical corrosion rates. In addition, it has been observed that corrosion rates obtained by electrochemical methods at elevated temperatures show a significant deviation in comparison to the results of gravimetric or analytical methods. However, electrochemical methods for determining corrosion rate are still widely used, often without verification of the results by direct methods as the weight loss method, analytical methods, etc.

There are several mechanisms of chemical corrosion, that explain why the flowed quantity of electricity during the anodic dissolution of metal is less than the quantity of electricity which is calculated on the basis of mass loss, using the Faraday's law. These mechanisms also provide an explanation why the effective valence is lower than the expected valence. The following chemical corrosion mechanisms are usually considered:

- forming metal ions of lower valence,

- mechanism of disintegration of the metal surface,

- mechanism by surface film control,

- mechanism of direct chemical dissolution.

\section{MECHANISMS OF CHEMICAL DISSOLUTION}

\subsection{Forming metal ions of lower valence}

When the metal, which dissolves, forms the ions with the valence greater than one, it can be 
assumed that the electrochemical reaction takes place gradually, probably via several one-electron reaction steps [4]. It was observed that during dissolution several metals pass through the step of monovalent ions, in the form of $\mathrm{Me}^{+}$(e.g. $\mathrm{Cu}, \mathrm{Zn}$, etc. $[5,6])$ or in the form of $\mathrm{MeOH}$ (e.g., Fe and so on [7]).

lons of low valence can diffuse into the electrolyte, if they are not adsorbed on the electrode surface. This was experimentally demonstrated by Hadži Jordanov and Dražić [8] for $\mathrm{Zn}^{+}$ ions. In such cases, diffusion rate of ions with a low valence from the electrode into the solution depends on hydrodynamic conditions. Thus, the apparently low valence depends on the hydrodynamic conditions in the vicinity of the electrode surface. However, if the intermediates of low valence are strongly adsorbed on the electrode surface, their diffusion in the solution cannot be expected, and therefore the reduction of the apparent valence cannot be also expected.

\subsection{Mechanism of disintegration of metal surface}

Mechanical disintegration of the metal surface was suggested to explain the observed increase in the concentration of metal ions in the solution, above the expected concentrations. Straumanis [9] has analyzed the anomalous dissolution of zinc and aluminium and concluded that the mechanical disintegration of the investigated metals (chunk effect) was responsible for the low apparent valence. According to the proposed mechanism of mechanical disintegration, the separation of atom groups from the surface takes place during the dissolution of those metals. These groups of atoms are weakly bound to the surface and can be transported as metal particles into the solution. If the electrolyte is aggressive enough, e.g. the solution of sulphuric or hydrochloric acid, the spontaneous corrosion of the particles can be expected in these solutions. This results with accumulation of metal ions in the solution in an amount greater than that which corresponds to the flowed quantity of electricity. Also, the hydrogen evolution reaction takes place. Accordingly, the experimentally obtained apparent valence is lower than the expected valence. Marsh and Schaschl [10] have shown that iron in the sulphuric acid solution ( $\mathrm{pH} 2$ ) corrodes twice as fast due to the mechanical disintegration (chunk effect) than it was expected according to the results of electrochemical measurements. Vorkapić and Dražić [11] have shown that the anomalous dissolution of iron in sulphuric acid during prolonged cathodic polarization was partly caused by the mechanical disintegration of iron.

\subsection{Mechanism by surface film control}

The mechanism of chemical dissolution, which is controlled by the presence of protective film on metal surface, can explain the anomalous anodic behaviour of metals, which is manifested by reduced current efficiency and negative differential effect. This behaviour has been often noticed during dissolution of magnesium, zinc and aluminium.

There are different versions of this mechanism, most of which are based on the fact that these metals are covered with a passive film. The passive film is destroyed during the anodic dissolution, and then it is restored. Depending on the composition of the solution (e.g. in the presence of $\mathrm{Cl}^{-}$ion) the properties of the passive film change which leads to the occurrence of pits on the metal surface. The negative differential effect is manifested as increased hydrogen evolution with the increase in anodic current density. Hydrogen evolution during the anodic polarization of $\mathrm{Al}$ is usually explained by the formation of $\mathrm{Al}^{+}$ions and their reaction with water molecules, according to the following equation:

$$
\mathrm{Al}^{+}+2 \mathrm{H}_{2} \mathrm{O} \rightarrow \mathrm{Al}^{3+}+\mathrm{H}_{2}+2 \mathrm{OH}
$$

Hydrogen evolution was also observed during the occurrence of stress corrosion cracking and corrosion fatigue of austenitic and martensitic stainless steels, at anodic polarizations [12].

\subsection{Mechanism of direct chemical dissolution}

In the period from 1965. to 1980. Kolotyrkin and co-workers have published a number of papers in which they gave experimental verification of anomalous dissolution of metals during corrosion and cathodic polarization of the metals. Metal is cathodically polarized to different values of cathodic polarization over a long period of time to allow accumulation of the corresponding ions in the solution to a concentration high enough that its value can be determined by analytical methods. For a large number of metals it was found that total dissolution of the metals was much greater than the expected, and that the process of dissolution was independent on electrode potential. The anomalous dissolution was observed in $\mathrm{Fe}, \mathrm{Mn}$, $\mathrm{Co}, \mathrm{Cr}, \mathrm{Be}$, stainless steels and other metals [11,13-15].

Figure 1 shows a polarisation diagram for dissolution of several metals, which is obtained on the basis of the metal ions concentration determined by appropriate analytical methods. Anodic polarization curves deviate from the linear Tafel behaviour on negative potentials and become vertical, i.e. the dissolution becomes independent on electrode potential. In contrast to other metals, the anomalous dissolution of iron depends on the $\mathrm{pH}$, i.e. $\mathrm{H}^{+}$ions accelerate the dissolution. The overall reaction of chemical dissolution for all metals can be written as:

$$
\mathrm{M}+n \mathrm{H}_{2} \mathrm{O} \rightarrow \mathrm{M}^{\mathrm{n}+}+\mathrm{nOH}+\mathrm{n} / 2 \mathrm{H}_{2}
$$


A more complex mechanism, which is $\mathrm{pH}$ dependent, was proposed for $\mathrm{Fe}$ and $\mathrm{Cr}$ :

$$
\begin{aligned}
& \mathrm{M}+\mathrm{H}_{2} \mathrm{O} \rightarrow \mathrm{MOH}+\mathrm{H} \\
& \mathrm{MOH}+\mathrm{H}^{+} \rightarrow \mathrm{MOH}^{+}+\mathrm{H} \\
& 2 \mathrm{H} \rightarrow \mathrm{H}_{2}
\end{aligned}
$$

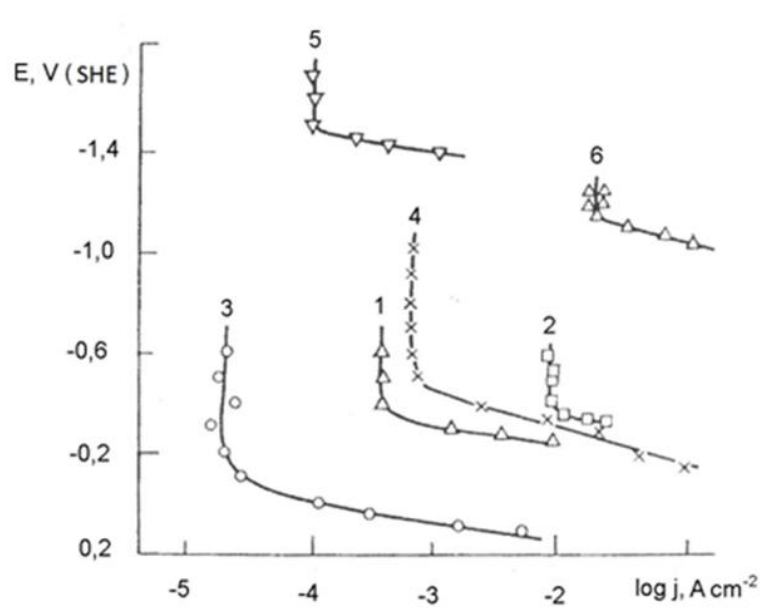

Figure 1 - Chemical dissolution rate dependence on electrode potential for: (1) iron in $0.05 \mathrm{M} \mathrm{H}_{2} \mathrm{SO}_{4}$ at $50{ }^{\circ} \mathrm{C}$, (2) chromium in $0.05 \mathrm{M} \mathrm{H}_{2} \mathrm{SO}_{4}$ at $50^{\circ} \mathrm{C}$, (3) nickel in $0.05 \mathrm{M} \mathrm{H}_{2} \mathrm{SO}_{4}$ at $50^{\circ} \mathrm{C}$, (4) aluminium in $0.05 \mathrm{M} \mathrm{H}_{2} \mathrm{SO} 4+0.1 \mathrm{M} \mathrm{NaCl}$ at $25^{\circ} \mathrm{C}$, (5) zinc in $0.05 \mathrm{M} \mathrm{H}_{2} \mathrm{SO}_{4}+0.25 \mathrm{M} \mathrm{Na}_{2} \mathrm{SO}_{4}$ at $25^{\circ} \mathrm{C}$, and (6) manganese in $0.05 \mathrm{M} \mathrm{H}_{2} \mathrm{SO}_{4}$ at $25^{\circ} \mathrm{C}$.

Reprinted with permission of Serbian Chemical Society, Ref. [16].

According to the Kolotyrkin`s opinion, chemical dissolution of metals, which occurs in accordance with the reaction 2 , or reaction $3-5$, is independent on electrode potential, so that the chemical dissolution reactions are presented by vertical lines in the electrochemical diagram of Wagner-Traud's type, as shown in Figure 2. Position of these lines is determined by the chemical reaction of metals with water and depends on the kind of metal, temperature and $\mathrm{pH}$ ( $\mathrm{pH}$-dependent reactions).

As can be seen in Figure $2 a$, when the rate of chemical dissolution is not much higher than the rate of electrochemical corrosion, the deviation from the straight line for the partial anodic current density can be observed only in the region of cathodic polarizations (vertical line $\mathrm{C} 1$ ). In the case when the rate of chemical dissolution is much larger than the rate of electrochemical corrosion, the deviation from the straight line of the partial anodic current density can be observed far before the corrosion potential, i.e. in the region of the real anodic polarization (vertical line C2 in Figure 2b).

Previous diagrams can also be analyzed from the standpoint of the electrochemical reaction of cathodic hydrogen evolution. Considering that the molecular hydrogen is formed by chemical reactions 2 or by reactions $3-5$, the total current density for the hydrogen evolution in dependence on electrode potential is the sum of the partial cathodic current density and the appropriate current density for the chemical reaction (vertical line $\mathrm{C} 1$ in Figure 2a and $\mathrm{C} 2$ in Figure $2 \mathrm{~b}$ ).

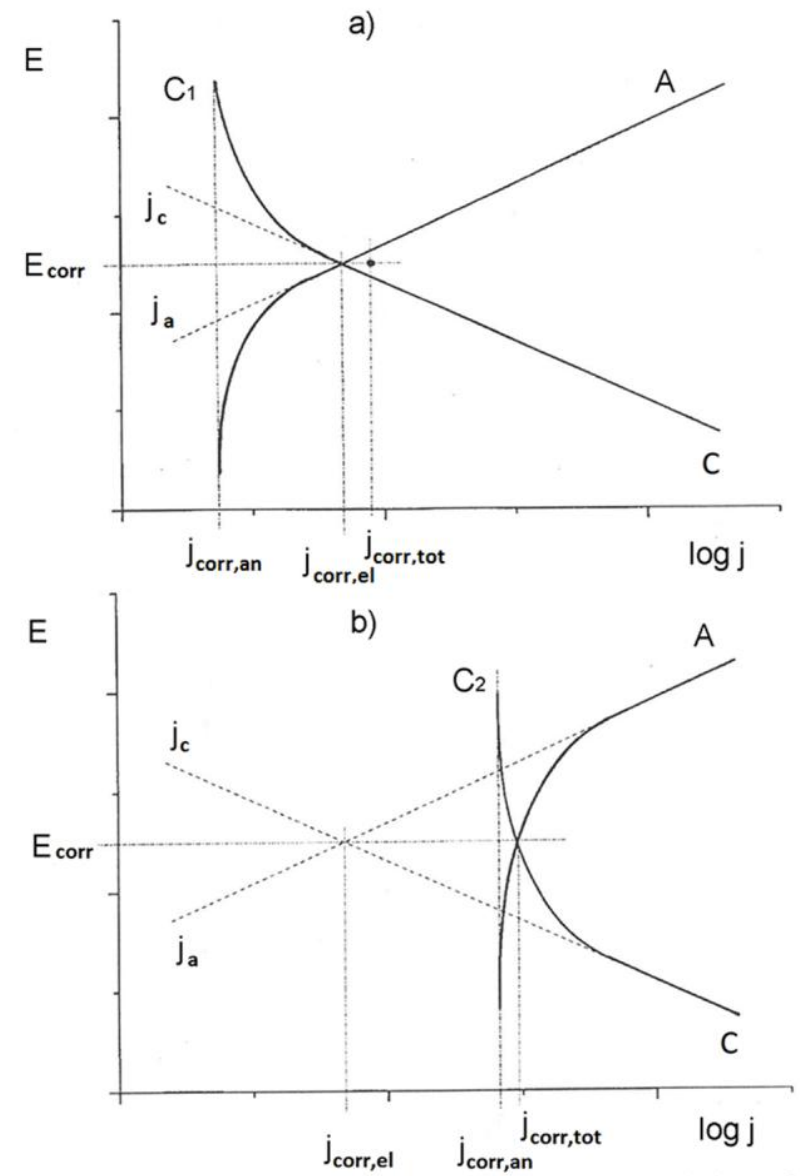

Figure 2 - Schematic presentation of rate of corrosion processes in dependence on electrode potential. CTafel line for cathodic hydrogen evolution, A-Tafel line for anodic dissolution of metal. a) C1-chemical dissolution of metal with low specific rate; C2chemical dissolution of metal with high specific rate.

The total rate is always the sum of all partial processes (solid lines).

Reprinted with permission of Serbian Chemical Society, Ref. [16].

The most important experimental results for iron, presented in the paper [17], are as follows: in the region of anodic potentials the total partial current of hydrogen evolution deviates from Tafel behaviour and passes into the approximately vertical line, similar to that for the case of chemical dissolution of Kolotyrkin's type (Figure 2a). Results for the anomalous hydrogen evolution are in accordance with the Kolotyrkin's results. Also, it was shown that the anomalous hydrogen evolution was independent on the solution $\mathrm{pH}$, in the range 0.5 to 3 , which is in contrast to the results of 
Kolotyrkin and Florijanovich [15]. The results in the paper [17] confirm the Kolotyrkin's model, according to which the anomalous dissolution and hydrogen evolution on iron occur by the chemical mechanism (Equation 6), simultaneously with the electrochemical process:

$$
\mathrm{Fe}+2 \mathrm{H}_{2} \mathrm{O} \rightarrow \mathrm{Fe}^{2+}+\mathrm{H}_{2}+2 \mathrm{OH}
$$

Electronic equilibrium between the metal and the solution is established when electrochemical partial processes occur at the same rate, i.e. at the corrosion potential, regardless to the progress of a chemical reaction (Equation 6). The chemical reaction does not involve the exchange of electrons. Thus, the corrosion potential for iron (and other metals that chemically corrode) is determined only by the electrochemical reactions, and chemical corrosion processes have no effect on it.

The results of Popić and Dražić on the metallic chromium [18-22] are important for the explanation of the role of chemical reactions during corrosion of metals. Polarization measurements, analytical determination of the concentration of $\mathrm{Cr}^{2+}$ and $\mathrm{Cr}^{3+}$ ions by atomic absorption spectroscopy AAS, the volume determination of the hydrogen evolved and gravimetric determination of mass loss of metals (chromium), were applied to study the anomalous dissolution of chromium.

The most important results are shown in Figure 3 [22]. Anodic and cathodic Tafel slopes are approximately $120 \mathrm{mV} \mathrm{dec}^{-1}$ with a narrow linear region of electrode potential before passivation. Similar polarisation diagrams for $\mathrm{pH} 2$ and $\mathrm{pH} 3$ have shown that the cathodic hydrogen evolution is $\mathrm{pH}$ dependent, with the reaction order $\sim 1$, for $\mathrm{H}^{+}$ions. Electrochemical anodic chromium dissolution is independent on $\mathrm{pH}$.

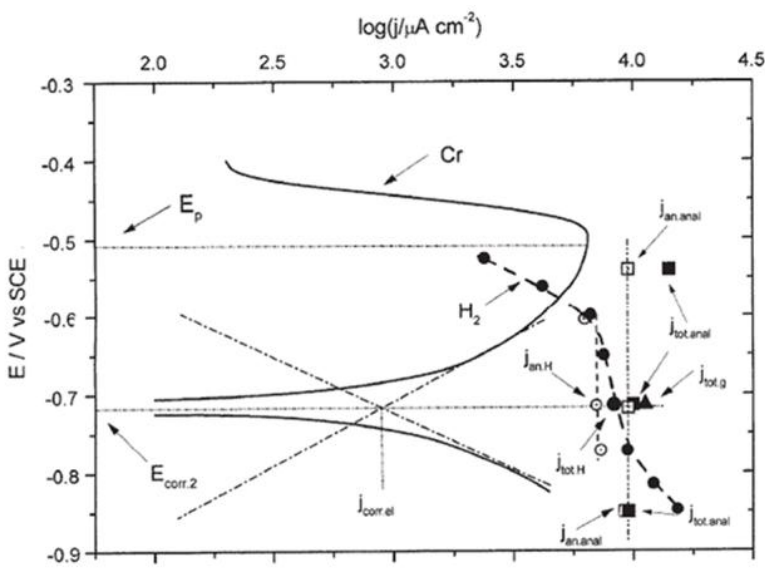

Figure 3 - Polarisation curves for $\mathrm{Cr}$ in $0.1 \mathrm{M}$ $\mathrm{Na}_{2} \mathrm{SO}_{4}+\mathrm{H}_{2} \mathrm{SO}_{4}, \mathrm{pH}$ 1. Hydrogen detected on $\mathrm{Pt}$ ring, or volumetrically (- - ). Calculated rates of chemical dissolution based on (घ) analytical data,

$(\bullet)$ volumetrical measurements, and ( $\mathbf{\Delta})$ gravimetrical measurements.

Reprinted with permission of Serbian Chemical Society, Ref. [22].
Dissolution of chromium occurs if its surface is activated, e.g. by polarization with the cathodic current density of $\sim 50 \mathrm{~mA} \mathrm{~cm}^{-2}$, for a few tens of seconds. In this way, the thin oxide film on chromium surface is reduced, which was formed spontaneously in air. Corrosion potential of nonactivated surface of chromium is much more positive $(-0.4 \mathrm{~V}$ vs. SCE) than the corrosion potential of the activated surface.

Heumann and Diekotter [23], Wilde and Hodge [24], Sukhotin and Khoreva [25] and Popić and Dražić [19-21] have observed that two stable corrosion potentials are established on chromium in deaerated sulphuric acid solution. First corrosion potential is established for the reaction of hydrogen evolution on the passive surface of chromium and the reaction of anodic dissolution of chromium through the passive film. The other corrosion potential is established for the reaction of hydrogen evolution on the activated, clean surface of chromium and the reaction of active anodic dissolution of chromium.

Figure 3 shows also the results obtained by volumetric measurements of the total volume of hydrogen evolved. The volume of hydrogen evolved is converted into an equivalent current density. In the cathodic region the total hydrogen evolution (dashed line in Figure 3 ) is significantly greater than the electrochemical hydrogen evolution. It is also the case in the vicinity of the corrosion potential and in the region of anodic polarizations. In the region of passivation potentials, hydrogen evolution is significantly reduced.

All three applied methods (volumetric, AAS and measurement of mass loss) gave approximately the same result for the chemical dissolution of chromium, thus confirming the Kolotyrkin's view about chemical corrosion.

Based on the papers [19-21] the following mechanism of chemical dissolution of chromium in acidic solutions has been proposed:

$$
\begin{aligned}
& \mathrm{Cr}+\mathrm{H}_{2} \mathrm{O} \rightarrow \mathrm{CrOH}_{a d s}+\mathrm{H} \\
& \mathrm{CrOH}_{a d s}+\mathrm{H}_{3} \mathrm{O}^{+} \rightarrow \mathrm{CrOH}^{+}+\mathrm{H}+\mathrm{H}_{2} \mathrm{O} \\
& \mathrm{CrOH}^{+}+\mathrm{H}_{3} \mathrm{O}^{+} \rightarrow \mathrm{Cr}^{2+}+\mathrm{H}_{2} \mathrm{O}
\end{aligned}
$$

This mechanism is similar to the mechanism of chemical dissolution for iron which was proposed by Kolotyrkin [15]. It should be noted that the reaction of chemical dissolution of chromium takes place only on a clean metal surface. The formation of passive film inhibits this reaction, since water molecules cannot come into the contact with the metal atoms.

In addition, it has been found that the temperature influences the reaction of chemical dissolution of chromium more significantly than the reaction of electrochemical corrosion of chromium. 
In the paper [19] it is shown that the apparent activation energy of chemical dissolution of chromium is $63.1 \mathrm{~kJ} \mathrm{~mol}^{-1}, 66.9 \mathrm{~kJ} \mathrm{~mol}^{-1}$ for the electrochemical reaction of anodic dissolution of chromium and $19.5 \mathrm{~kJ} \mathrm{~mol}^{-1}$ for the electrochemical reaction of hydrogen evolution. In accordance with the Arrhenius equation, the rate of the process with a higher activation energy increases more at elevated temperatures, than the rate of the process with a lower activation energy, as shown in Figure 4.

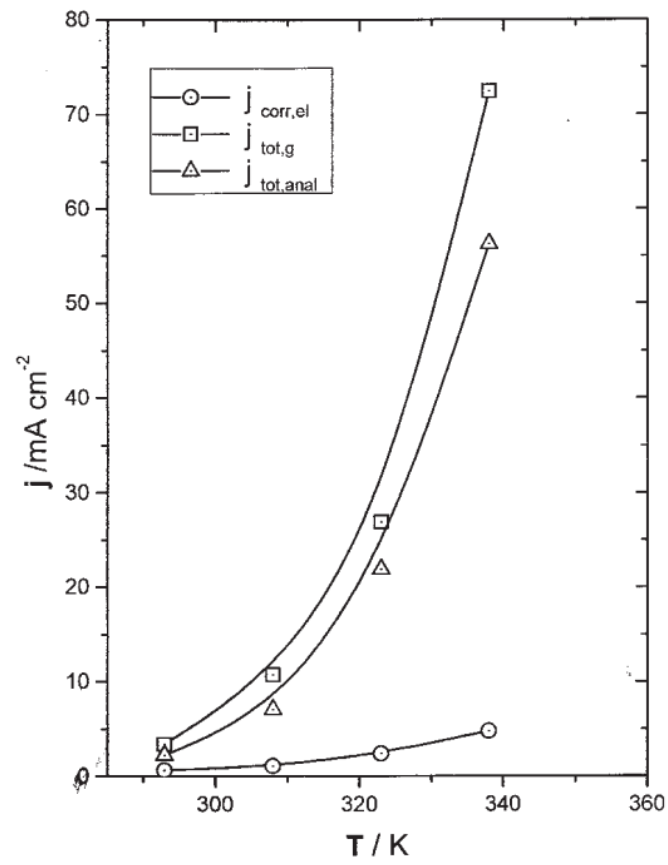

Figure 4 - Corrosion current density for chromium, obtained gravimetrically ( $\square$ ), analytically $(\Delta)$, or electrochemically (o) at different temperatures. Reprinted with permission of Serbian Chemical Society, Ref. [19].

The rate of chemical dissolution of chromium is the difference between the total rate and the rate of electrochemical dissolution. As can be seen in Figure 4, the current density of chromium chemical dissolution increases more rapidly with the increase in temperature than the current density of electrochemical dissolution. Greater influence of temperature on the rate of chemical dissolution than on the rate of electrochemical dissolution is due to the differences in values of activation energies, as previously noted.

Figure 5 shows the time dependence of the total dissolution current of chromium and the current of electrochemical corrosion of chromium, at $333 \mathrm{~K}[26]$.

The rate of chemical dissolution of chromium is $\mathrm{pH}$ dependent, as shown in Figure 6. This suggests that the hydrogen ions are involved in the chromium chemical dissolution.

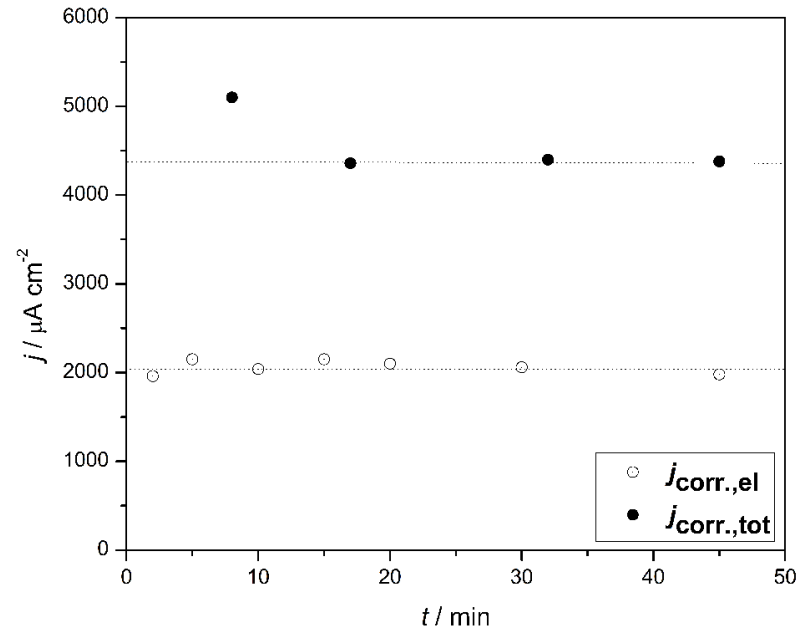

Figure 5 - Time dependence of total current density of chromium dissolution and current density of chromium electrochemical corrosion, at $333 \mathrm{~K}$. The total current density of chromium dissolution was determined by AAS. The current density of chromium electrochemical corrosion is determined by Stern-Geary method.

Reprinted with permission of Serbian Chemical Society, Ref. [26].

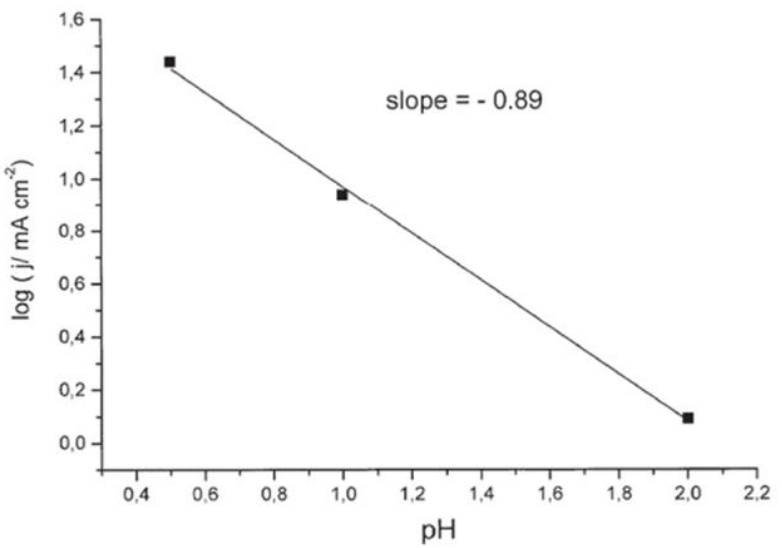

Figure 6 - $p H$ dependence of chemical dissolution rate for chromium.

(Reprinted with permission of Serbian Chemical Society, Ref. [22])

The influence of texture of the metallic chromium and texture of the electrolytically deposited chromium coating on the rate of chemical or electrochemical dissolution is discussed in [27]. It was demonstrated that chromium with the texture (110) dissolves more slowly than chromium with the texture (111). Mechanisms of hydrogen evolution on chromium during chemical and electrochemical corrosion are presented in detail in [28]. The nature of corrosion potentials formed on the chromium, and chromium-nickel stainless steels is discussed in detail [29-31]. Chromium in deaerated aqueous solutions of $\mathrm{H}_{2} \mathrm{SO}_{4}$, with and without $\mathrm{NaCl}$, shows two stable corrosion potentials. One 
corrosion potential is formed on the passivated chromium surface, and the second corrosion potential is formed on the clean surface of chromium, without passive film. On Cr-Ni stainless steels only one corrosion potential is established [29-31].

\section{CONSEQUENCES OF CHEMICAL DISSOLUTION}

The consequences of chemical dissolution of chromium were observed in different cases.

The aqueous solution for electrodeposition of chromium contains $\mathrm{CrO}_{3}$ (up to $600 \mathrm{~g} \mathrm{dm}^{-3}$ ) and $\mathrm{H}_{2} \mathrm{SO}_{4}$ (up to $6 \mathrm{~g} \mathrm{dm}^{-3}$ ). The current efficiency for deposition of chromium is 13 to $15 \%$. Low current efficiency is usually explained by the fact that the rate of electrochemical hydrogen evolution on the chromium is 3 to 4 times greater than the rate of chromium precipitation. However, according to Dražić [32], this effect is the result of high rate of chromium chemical dissolution, which takes place simultaneously with the chromium cathodic deposition. Net deposition of chromium is achieved when the equilibrium is established between the rate of chromium chemical dissolution and the rate of chromium cathodic deposition. This means that it is necessary to overcome the critical value of cathodic current which is equivalent to the current of the chemical dissolution. Inhibition of the reaction of chromium chemical dissolution can influence the increase in current efficiency of chromium.

Also, it was observed that during anodic polarization of aluminium, the unexpected hydrogen evolution $\left(\mathrm{H}_{2}\right.$ bubbles) occurs from individual pits on the surface of aluminium [33]. At the same time, the anodic current efficiency for aluminium is $85-90 \%$, in accordance with the mechanism of chemical dissolution, which is controlled by the surface film [34], as is previously stated. This phenomenon is known as negative differential effect in Russian literature [35].

During stress corrosion cracking and corrosion fatigue of stainless steels, it was found that accumulation of adsorbed hydrogen usually occurs at the bottom of cracks. This leads to a weakening of mechanical properties, which explains relatively rapid crack propagation through the stressed metal [36]. The presence of hydrogen at the bottom of cracks cannot be explained from the electrochemical point of view.

Chemical corrosion of white cast iron with a high content of chromium and its consequences are discussed in the paper [37].

\section{CONCLUSIONS}

Chemical dissolution of metals takes place simultaneously with electrochemical dissolution of metals. Chemical dissolution does not depend on the electrode potential and in certain conditions is the dominant process of dissolution. During chemical dissolution of metals in acidic environ- ments hydrogen evolves, whereby hydrogen evolution also is not dependent on electrode potential, i.e. it is not subjected to the laws of electrochemical kinetics.

Several mechanisms of chemical corrosion of metals are described, such as: formation of metal ions of lower valence, mechanism of disintegration of metal surface, mechanism of control by surface film and mechanism of direct chemical dissolution. These mechanisms explain why, in chemical dissolution of metals, the measured quantity of electricity during dissolution of metal is less than the quantity of electricity which is calculated by the mass loss method. The mechanism of direct chemical dissolution and a large number of influencing factors (temperature, $\mathrm{pH}$ value, etc.) were discussed in more detail.

\section{Acknowledgement}

This work was co-financed from the Ministry of Education, Science and Technological Development of the Republic of Serbia through projects III 45019 and TR 35021.

\section{REFERENCES}

[1] M.Stern, A.L.Geary (1957) Electrochemical Polarization: A Theoretical Analysis of the Shape of Polarization Curves, J. Electrochem. Soc., 104 (1), 56-63.

[2] F.Mansfeld (1976) in Advance in Corrosion Science and Technology, Vol. 6, Eds. M.G.Fontana and R.W.Staehle, Plenum press, New York.

[3] M.Pražak (1974) The Polarization Resistance Method for Corrosion Testing, Werst. Korros., 25 (2), 104-112.

[4] B.E.Conway, J.O'M.Bockris (1960) On the Calculation of Potential Energy Profile Diagrams for Processes in Electrolytic Metal Deposition, Electrochim. Acta, 3 (4), 340-366.

[5] E.Mattson, J.O`M.Bockris (1959) Galvanostatic studies of the kinetics of deposition and dissolution in the copper + copper sulphate system, Trans Faraday Soc., 55, 1586-1601.

[6] D.M.Dražić, S.K.Zečević (1978) On the Mechanism of Zinc Dissolution in Acid Solutions, Bull. Serb. Chem. Soc. Beograd, 43 (4), 141-147.

[7] J.O`M.Bockris, D.M.Dražić, A.R.Despić (1961) The Electrode Kinetics of the Deposition and Dissolution of Iron, Electrochim. Acta, 4 (2-4), 325-361.

[8] S.A.Hadži Jordanov, D.M.Dražić (1973) The Kinetics and Mechanism of Electrochemical Deposition of Zinc in Acid Sulfate Solutions, Bull. Serb. Chem. Soc. Beograd, 38 (9-10), 529-544.

[9] M.E.Straumanis (1961) Valency of lons Formed during Anodic Dissolution of Metals in Acids, J. Electrochem. Soc., 108 (12), 1087-1092.

[10] G.A.March, E.Schaschl (1960) The Difference Effect and the Chunk Effect, J. Electrochem. Soc., 107 (12), 960-965

[11] L.Ž.Vorkapić, D.M.Dražić (1979) The dissolution of iron under cathodic polarization, Corrosion Sci., 19 (9), 643-651. 
[12] R.H.Jones (1998) Stress Corrosion Cracking, in ASM Handbook, Metals Handbook, Vol. 13, Corrosion, ASM International, Ohio, p 145-161.

[13] Ya.M.Kolotyrkin, T.R.Agladze (1967) Osobenosti rastvoreniya marganca $\mathrm{v}$ kislih elektrolitakh, Zashch. Metal., 3 (4), 413-418.

[14] V.M.Knyazheva, Ya.M.Kolotyrkin, A.A. Kruzhkovskaya (1970) O mekhanizme rastvoreniya khromo-nikel-margancevih stalej $v$ sernoj kislote, Zashch. Metal., 6 (3), 265-273.

[15] Ya.M.Kolotyrkin, G.M.Florianovich (1984) Anomalnoe rastvorenie metallov. Eksperimentalnie fakti i in teoreticheskoe tolkovanie, Zashch. Metal., 20 (1) 14-24.

[16] D.M.Dražić, J.P.Popić (2005) Anomalous dissolution of metals and chemical corrosion (Review), J. Serb. Chem. Soc., 70 (3), 489-513.

[17] D.M.Dražić, J.P.Popić (2000) Chemical dissolution of iron in aqueous solutions, Russ. J. Electrochem., 36 (10), 1043-1050.

[18] D.M.Dražić, J.P.Popić (2002) Dissolution of chromium in sulfuric acid, J. Serb. Chem. Soc., 67 (11), 777-783.

[19] J.P.Popić, D.M.Dražić (2003) Electrochemistry of active chromium. Part III. Effects of temperature, J. Serb. Chem. Soc., 68 (11), 871-883.

[20] D.M.Dražić, J.P.Popić (2004) Electrochemistry of Active Chromium: Part 1-Anomalous Corrosion and Products of Chromium Dissolution in Deaerated Sulfuric Acid, Corrosion, 60 (3), 297-304.

[21] J.P.Popić, D.M.Dražić (2004) Electrochemistry of active chromium: Part II. Three hydrogen evolution reactions on chromium in sulfuric acid, Electrochim. Acta, 49 (27), 4877-4891.

[22] D.M.Dražić, J.P.Popić, B.Jegdić, D.VasiljevićRadović (2004) Electrochemistry of active chromium. Part IV. Dissolution of chromium in deaerated sulfuric acid, J. Serb. Chem. Soc., 69 (12), 1099-1110.

[23] Th.Heumann, F.W.Diekotter (1963) Untersuchungen über das elektrochemische Verhalten des Chroms in schwefelsauren Lösungen im Hinblick auf die Passivität, Ber. Bunsenges. Phys. Chem., 63 (7), 671-680.
[24] B.E.Wilde, F.G.Hodge (1969) The cathodic discharge of hydrogen on active and passive chromium surfaces in dilute sulphuric acid solutions, Electrochim. Acta, 14 (7), 619-627.

[25] A.M.Sukhotin, N.K.Khoreva (1982) Passivnost khroma. Osobenosti katodnogo aktivirovaniya khroma, Electrokhimiya, 18 (1), 132-134.

[26] B.Jegdić, D.M.Dražić, J.P.Popić (2007) Structural effects of metallic chromium on its electrochemical Behavior, J. Serb. Chem. Soc., 72 (6), 563-578.

[27] D.M.Dražić, B.Jegdić, J.P.Popić (2005) Uticaj strukture metalnog hroma na njegovu elektrohemijsku i hemijsku koroziju, Zaštita materijala, 46 (2), 29-34.

[28] B.Jegdić, B.Bobić, A.Jegdić, M.Stevanović (2015) Mechanisms of hydrogen evolution on chromium, Minning and Metallurgy Engineering Bor, 3,145-156.

[29] B.Jegdić, D.M.Dražić, J.P.Popić (2006) Influence of chloride ions on the open circuit potentials of chromium in deaerated sulfuric acid solutions, J. Serb. Chem. Soc., 71 (11), 1187-1194.

[30] B.Jegdić, D.M.Dražić, J.P.Popić (2008) Open circuit potentials of metallic chromium and austenitic 304 stainless steel in aqueous sulphuric acid solution and the influence of chloride ions on them, Corr. Sci., 50, 1235-1244.

[31] B.Jegdić, D.M.Dražić, J.P.Popić (2006) Corrosion potential of 304 stainless steel in sulfuric acid, J. Serb. Chem. Soc., 71 (5), 543-551.

[32] D.M.Dražić, J.P.Popić (2003) Department of Technical Sciences, SANU, book 34, Belgrade.

[33] H.Keasche (1984) Die Korrosion der Metalle, Russian translation, Metalurgiya, Moskva.

[34] D.M.Dražić, J.P.Popić (1999) Corrosion rates and negative difference effects for $\mathrm{Al}$ and some $\mathrm{Al}$ alloys, J. Appl. Electrochem., 29 (1), 43-50.

[35] N.D.Tomashov (1959) Teoriya korozii i zaschiti metallov, AN SSSR, Moskva.

[36] D.M.Dražić (1996) Department of Technical Sciences, SANU, book 2, Belgrade.

[37] J.P.Popić, B.Jegdić (2008) Korozija visokohromnog belog gvožđa u kiseloj sredini, Zaštita materijala, 49 (2), p. 15-23.

\section{IZVOD}

\section{HEMIJSKA KOROZIJA METALA I LEGURA}

U ovom preglednom radu analizirana je hemijska korozija metala i legura u rastvorima elektrolita. Pokazano je da se gvožđe, hrom i neki drugi metali i legure rastvaraju mnogo brže nego što je njihova brzina korozije određena elektrohemijskim metodama. To znači da se istovremeno sa elektrohemijskim rastvaranjem odvija i hemijsko rastvaranje, koje ne zavisi od potencijala. $U$ nekim uslovima hemijsko rastvaranje metala je dominantan proces rastvaranja. Opisano je više mehanizama hemijske korozije. Takođe, razmatrane su posledice hemijskog rastvaranja različitih metala i legura, kao i pojava izdvajanja vodonika pri hemijskom rastvaranju. Proces izdvajanja vodonika pri hemijskoj koroziji ne podleže zakonitostima elektrohemijske kinetike.

Ključne reči: korozija, hemijsko rastvaranje, elektrohemijsko rastvaranje, gvožđe, hrom.

Pregledni rad

Rad primljen: 25. 12. 2015.

Rad prihvaćen: 21. 01. 2016.

Rad je dostupan na sajtu: www.idk.org.rs/casopis 